\title{
Measurement of the Thermal Conductivity and Rainwater Resistance of the Stabilized Mound Soil with Cement
}

\author{
Abdallah DADI Mahamat, Ali Abakar, Alexis Mouangué Nanimina, Abdallah Bannah Mahamat
}

\begin{abstract}
This study is the result of experimental work in the field thermal of buildings. The study focuses on mounds termite's clays. In this study a thermal analysis by the measurement of the thermal conductivity and the thermal resistance is carried out. This approach to determining the characteristics of materials has led to a better understanding of the possible choice of local building materials available in Chad. The estimation of thermal parameters of building materials plays a key role in a large number of scientific and industrial fields. Our choice has been focused on the termite mound soil which is currently of interest as a result of availability, energy crisis and that of housing. Unlike cement concrete, thé soil has long been used as a building material with practically many environmental benefits and considerable energy savings.

The results obtained showed that the materials we used have a appreciable thermal properties. Brick from naturally occurring mound termite soil has better thermal resistance than brick made from mound termite soil, which means it is worked in advance. The influence of density on thermal resistance has been demonstrated. The stabilization of the cement reinforced the structure of the material and its resistance to erosion of the rain water.
\end{abstract}

Keywords: mound termites soil, thermal resistance, building materials, thermal comfor.

\section{INTRODUCTION}

Nowadays, global warming is one of the major problems that worries all humanity with its harmful effects. Heat, freshness and the cost of excessive electrical energy are disrupt thermal comfort. One of the appropriate solutions to overcome this problem is the thermal insulation of our buildings or the use of insulating materials for construction.

Revised Manuscript Received on December 30, 2019.

* Correspondence Author

Abdallah DADI Mahamat*, Department of Energy Engineering, INSTA National Highter Institute of Sciences and Technicals, Abeche, Chad. E-mail: abdallah.dadi@univ-thies.sn

Ali Abakar, Department of Civil Engineering, ENSTP National Highter School of Public Works, N'djamena, Chad. E-mail: koudouri2019@gmail.com.

Alexis Mouangué Nanimina, Department of Mecanical Engineering, INSTA National Highter Institute of Sciences and Technicals, Abeche, Chad. E-mail: alexisnanichad@gmail.com

Abdallah Bannah Mahamat, Department of Mecanical Engineering, INSTA National Highter Institute of Sciences and Technicals, Abeche, Chad. E-mail: addibannah@yahoo.fr

(C) The Authors. Published by Blue Eyes Intelligence Engineering and Sciences Publication (BEIESP). This is an open access article under the CC BY-NC-ND license (http://creativecommons.org/licenses/by-nc-nd/4.0/)
The valorization of the local materials becomes a necessity in the field of construction where clay is the most used material. In this study, we tested several mixtures of mound termite clay materials and then stabilized with cement percentage.

The aim is to valorize cement materials and their characteristics. Many studies show that the thermal Characteristics of building materials are related to the conditions of use, in particular, temperature and water content. In this work, measurements are made in the mass proportion of the soil.

The objective of this work is to do a technical study of local building materials, in order to broaden their current field of use and also to promote them as substitutes for the materials currently used. This leads us to develop the following theme: "Measurement of thermal conductivities of local building materials based on termite mound clay in Chad".

This work was carried out at the Materials and Energy Laboratory of the National Institute of Science and Technology of Abeche (INSTA).

During this work, we were interested in a thermal characterization study of the termites mound clay stabilized with cement (concrete brick).

\section{THE USED MATERIALS}

\section{A. The soil}

Clay is a sedimentary rock, derived from the decomposition of mineral species composed mainly of alumina silicate. Naturally rich in mineral salts, magnesium, silicon, calcium, potassium and trace elements. That's all the human body needs. For thousands of years, humanity has relied on clay as a building material. The reason is simple: the earth is used without having to add a lot of energy or chemical processes, it is naturally a good building material. The objects produced are then bricks, tiles and others. Due to its unique ubiquity and properties, clay remains today one of the most used earth materials in housing construction and many other areas [1]. However, the quality of the clay varies from one medium to another and varies according to the depth. Given its abundance in our country Chad and its usefulness, clay plays a very important role in the construction of buildings. In recent years, African countries, anxious to reduce the cost of investment compared to imported materials, have a great interest in the study and development of local building materials.

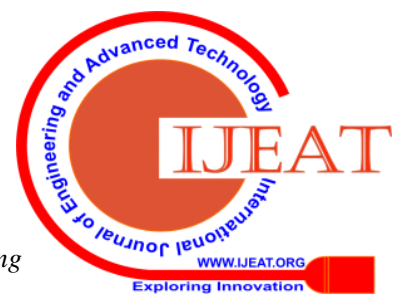


The import materials are too expensive and not in keeping with the real needs of the population. They are also major consumers of energy.

Clay is a material that has been used for a very long time in many fields [2]. Especially in the field of construction. Nowadays, it can be used in a mixture with waste such as cow dung or millet pod, to improve its thermal performance.

It is generally used for its mechanical characteristics, but it also plays the role of thermal insulation.

\section{B. Mound termite soil}

Good Termites are insects that live in society. At home, construction activity is widespread. Termites build nests of various shapes and sizes, usually consisting of an interconnected cavity assembly, connected to the exterior by an underground or covered gallery system. The termite nest on which we extracted materials for our study is of cathedral type, the point common to this structure is the fragmentation of the inhabited space in a multitude of rooms partitioned, but interconnected by small passages [3]. To build their nests, termites must coordinate their actions. We can say that termites are endowed with a faculty close enough to the human intelligence in terms of habitat and thermal comfort, allowing them to glimpse the objective of their construction work and to conceive a plan of execution for them to enforce [4]. The functioning of these societies is based on sophisticated communication systems and a division of labor within the working class, termites use the chemical signals deposited on the ground to communicate and guide their movement to the harvesting areas. The termite mounds are built with a mortar consisting of clay elements soaked with saliva and loaded with fine sand, and sometimes mixed with their excrement [5].

In Chad we have an area of several dozen kilometers called "Ganatir" which means termite fields.

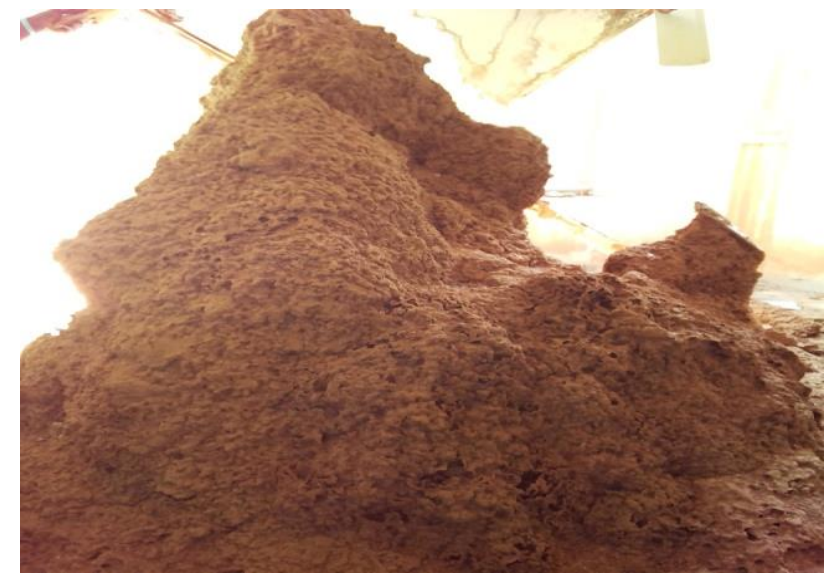

Fig. 1.Cathedral mound clay

Table I : survey of termites indifiers [5]

\begin{tabular}{|c|c|c|}
\hline Type of mound clay & Family & species \\
\hline $\begin{array}{c}\text { Mushroom and } \\
\text { subconical }\end{array}$ & Termitidae & Cubitermes sankurensis \\
\hline Cathedral or dome & Termitidae & $\begin{array}{c}\text { Pericapritermes } \\
\text { chisognathus }\end{array}$ \\
\hline
\end{tabular}

\section{Cement}

The cement used in this article is Portland cement supplied by the Sudanese company ATBARA. It is the cement most used in the constructions in Abeche. It is of type CEM II / A-42.5. Portland cement is a mixture of clinker and filler. The clinker is formed at high temperature, from limestone (80\%) and clay (20\%). The cement consists of clinker (75\%), gypsum (5\%) and limestone (20\%) [6].

\section{Clay sampling and sample formulation}

Our work is focused on the termite clay collected right next to energetic laboratory and INSTA material. In fact, the termite clay is a light earth compared to simple clay. The upgrading of these widely available, less expensive building materials is the main goal of our work. However, we will strengthen it with cement [6].

We made samples in the natural state and the other samples are made after the addition of water and a mass proportion of the cement. During the preparation, the clay is formed in modeling clay by adding water. The malleability of this clay varies according to the mineralogical nature of the clay used, its fineness and its composition in inert elements. Indeed, scientific work must always have a clear and exact method. For that, we made measurements to know the percentage of each element which composes the mixture. Our goal is to make bricks with only clay termite, then with cement dosage. In all cases there is the intervention of water. For the clay mound mixture with cement we have 5 formulations in mass proportion of 2 to $10 \%$ :

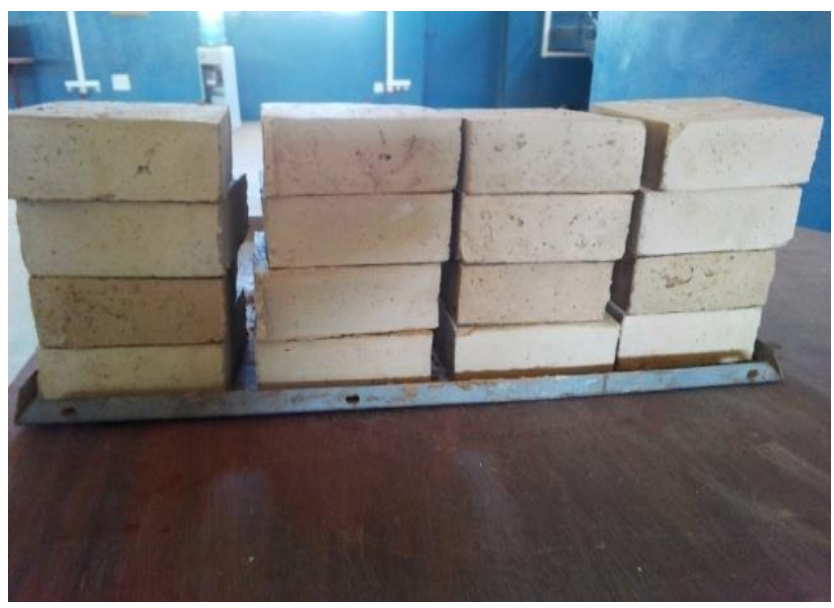

Fig. 2. Samples of bricks

In our study, we made samples of $12 \mathrm{~cm} * 12 \mathrm{~cm}$ with a thickness of $3.7 \mathrm{~cm}$. The following table presents the references of our samples after drying.

Table 2: References of clay of termite samples

\begin{tabular}{|c|c|c|c|c|c|c|c|}
\hline \multirow{2}{*}{ Samples } & \multicolumn{2}{|c|}{ Composition } & \multirow{2}{*}{$\mathrm{m}$} & $\mathrm{e}$ & $\mathrm{S}$ & $\mathrm{V}$ & $\rho$ \\
\cline { 2 - 3 } & Clay & Cement & & & & & \\
\hline ET0 & 100 & 0 & 0,61 & 0,03 & 0,014 & 0,00053 & 1152 \\
\hline ET1 & 100 & 0 & 0,80 & 0,03 & 0,014 & 0,00053 & 1516 \\
\hline $\mathrm{ET}_{2}$ & 98 & 2 & 0,91 & 0,03 & 0,014 & 0,00053 & 1711 \\
\hline
\end{tabular}




\begin{tabular}{|c|c|c|c|c|c|c|c|} 
ET3 & 96 & 4 & 0,9 & 0,03 & 0,014 & 0,00053 & 1783 \\
\hline ET4 & 94 & 6 & 0,98 & 0,03 & 0,014 & 0,00053 & 1854 \\
\hline ET5 & 92 & 8 & 0,99 & 0,03 & 0,014 & 0,00053 & 1861 \\
\hline ET6 & 90 & 10 & 0,99 & 0,03 & 0,014 & 0,00053 & 1873 \\
\hline
\end{tabular}

\section{E. Description of the box method}

Measuring the thermal characteristics of materials in building construction is of great importance from an energy point of view. The characteristics that are necessary for the evaluation of thermal balances are: Thermal conductivity, thermal diffusivity, specific heat [7]. To measure these three parameters, we used the EI700 Measurement Cell which uses the box method, which is a steady-state method. Obtaining this regime is achieved by performing a unidirectional heat flow through a test sample, placing it between a warm and a cold environment, and then perform temperature measurements after temperature stabilization. The apparatus consists of: a measuring console, a cryostat and a box [8].

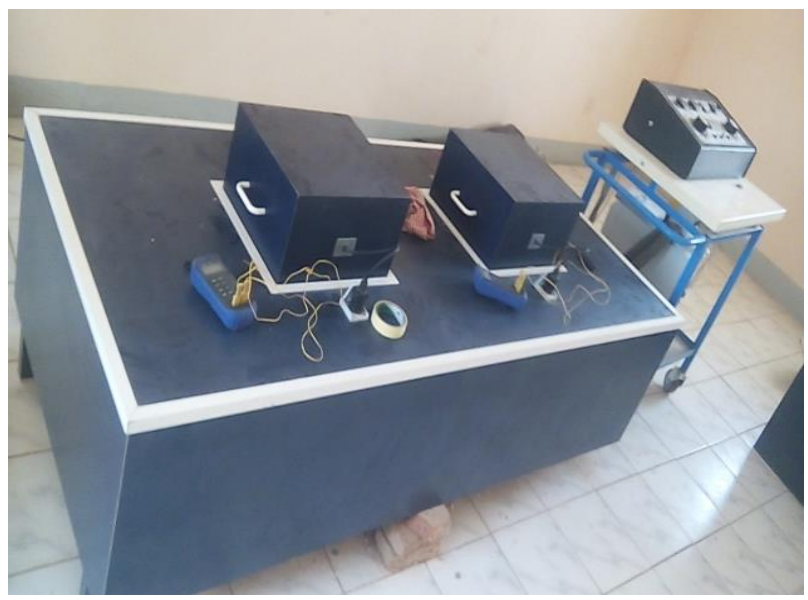

Fig. 3.Mesuring device for thermal conductivity EI 700

\section{F. Principle of measurement}

The cell EI700 comprises: The volume A maintained at a low temperature by means of a heat exchanger $\mathrm{R}$ situated at its base, through which cooled brine water (approximately -5 ${ }^{\circ} \mathrm{C}$.) passes through a cryostat $\mathrm{K}$, hot boxes, B1 coated, on the inner part of their upper face, a heating film $\mathrm{C}$ whose heat emission can be controlled using a rheostat. The sample $\mathrm{E}$ of the material to be tested is located between the box B1 and the capacity A in such a way that the lateral flows are negligible. By cooling $\mathrm{A}$ and heating $\mathrm{B} 1$, a temperature gradient is created between $\mathrm{B} 1$ and $\mathrm{A}$ such a way that the convective exchanges on the faces of $\mathrm{E}$ are zero. The temperatures are measured on both sides of the sample (in the center of these samples): TC and TF (hot and cold faces).

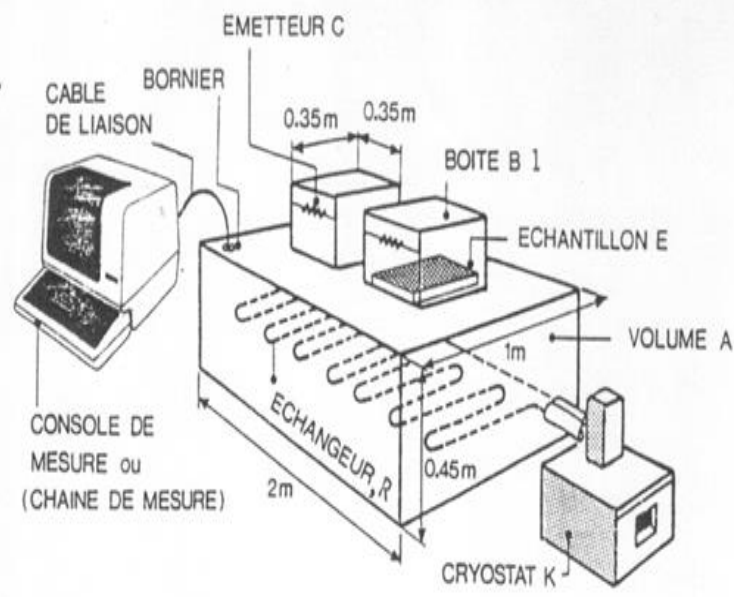

Fig. 4.View of the box cell EI700 [9].

\section{G. Calculation method of thermal conductivity $(\lambda)$}

The cell EI700 comprises: The volume A maintained at a low temperature by means of a heat exchanger $\mathrm{R}$ situated at its base, through which cooled brine water (approximately -5 ${ }^{\circ} \mathrm{C}$.) passes through a cryostat $\mathrm{K}$, hot boxes, B1 coated, on the inner part of their upper face, a heating film $\mathrm{C}$ whose heat emission can be controlled using a rheostat.

The sample $\mathrm{E}$ of the material to be tested is located between the box B1 and the capacity A in such a way that the lateral flows are negligible.

By cooling A and heating B1, a temperature gradient is created between B1 and A such that the convective exchanges on the faces of $\mathrm{E}$ are zero.

Temperatures are measured on both sides of the sample (in the center of these samples): TC and TF (hot and cold faces).

The cell EI700 includes: The volume A maintained at a low temperature by means of a heat exchanger $\mathrm{R}$ at its base, through which cooled brine water (approximately $-5{ }^{\circ} \mathrm{C}$.) passes through a cryostat $\mathrm{K}$, hot boxes, B1 coated, On the surface of the film, the film can be controlled using a rheostat.

The sample of the material to be tested is located between the box and the capacity in such a way that the lateral flows are negligible [7].

By cooling A and heating B1, a temperature gradient is created between B1 and A such a way that the convective exchanges on the faces of $\mathrm{E}$ are zero.

Temperatures are measured on both sides of the sample (in the center of these samples): TC and TF (hot and cold faces)

$\lambda_{T}=\frac{e}{s\left(T_{c}-T_{f}\right.}\left(Q-C\left(T_{b}-T_{a}\right)\right.$

After obtaining the steady state, the expression of the thermal conductivity of the sample is given by:

$\lambda_{e}=\frac{s_{T}}{s_{e}} \lambda_{T}-\frac{s_{p}}{s_{e}} \lambda_{p}$

$\lambda_{\mathrm{T}}, \lambda_{\mathrm{p}}, \mathrm{s}_{\mathrm{e}}$ and $\mathrm{s}_{\mathrm{p}}$ are the total thermal conductivity, the themal conductivity of polystyrene, the total area and the area of polystyrene respectively. 
We used a voltage of $55 \mathrm{~V}$, which does not correspond to the curve of the variation of the voltage across the heating resistor as a function of the density. The choice of tension was made by our framer. Knowing the voltage that is $55 \mathrm{~V}$ and the resistance that is $1600 \Omega$ (measured using an ohmmeter), we can determine the power emitted by the following formula [10]:

$Q=\frac{U^{2}}{R_{p}}$

$\mathrm{C}$ : a constant of the hot box, $\mathrm{C}=0.16\left(\mathrm{~W} /{ }^{\circ} \mathrm{C}\right)$. $\mathrm{U}$ is the voltage value and $R_{p}$ the resistance of the hotplate.

\section{RESULTATS}

\section{A. Measurement of thermal conductivity}

Before each measurement of the conductivity, we must know for each sample its geometrical parameters (thickness, surface, mass, volume and density). It is known that the samples do not contain moisture. After obtaining the steady state, we take the temperature on both sides of the sample, the boxes and that of the experimental room.

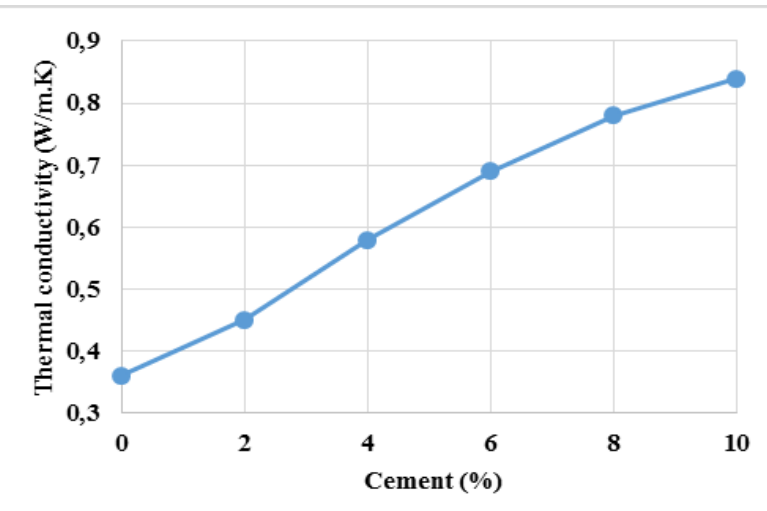

Fig. 5.Evolution of thermal conductivity of the dung termite clay according to the addition cement

The evolution of the thermal conductivity of the mound clay as a function of the addition of the cement has been shown in FIG. 5. It will be noted in this figure that the conductivity is an increasing function. This is because the mound clay samples we have studied are porous materials. Indeed, the thermal conductivity of the mound clay being lower than that of the cement, the addition of the cement for its stabilization will tend to raise its thermal conductivity. The more cement is added, the higher the thermal conductivity.

\section{B. Deduction of the thermal resistance $\mathbf{R}$}

The values of the thermal conductivity $(\lambda)$ and the thickness (e) are known, we can calculate the thermal resistance $(\mathrm{R})$ by the following formula [11]:

$R=\frac{e}{\lambda}$

Thermal resistance involves the thickness of the sample to characterize the passage of the heat flux. The results are shown in Figure 6.

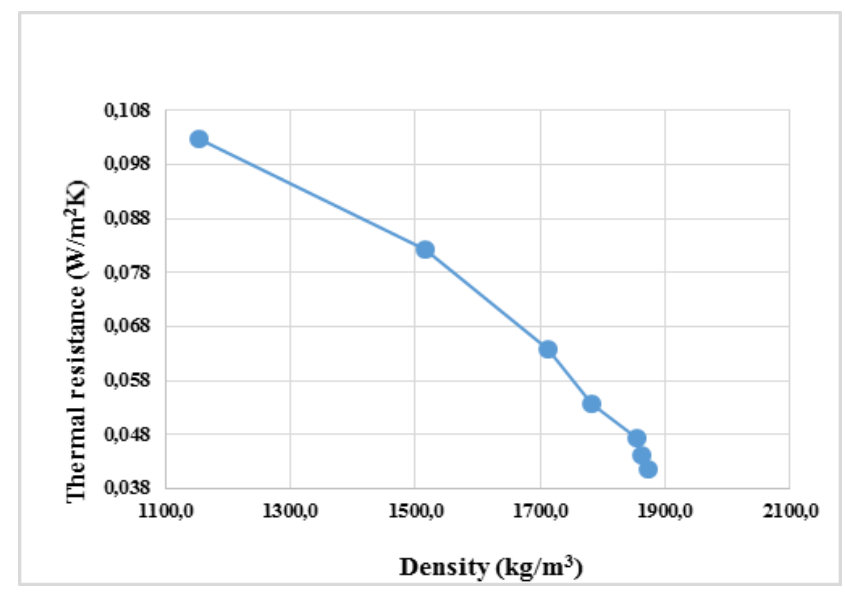

Fig. 6.Evolution of the thermal resistance of the dung termite clay with respect to the density

The values of the thermal resistance of the mound clay were used to draw the curve of Figure 6 which represents the evolution of the thermal resistance as a function of the density.

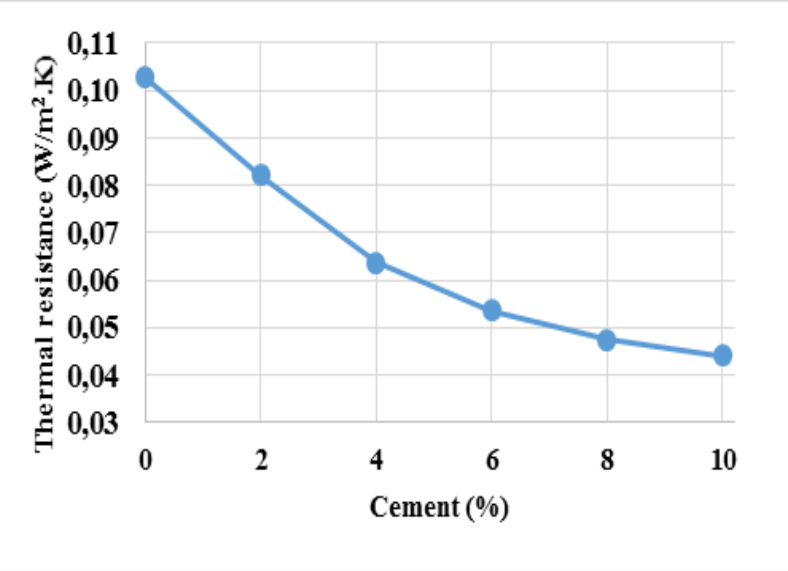

Fig. 7.Evolution of thermal resistance of dung termite clay with cement

We notice that the curve of the thermal resistance is decreasing. When the thermal resistance is high, the density is small. The thermal conductivity of the clay s ample of termite mound is of the order of $0.37 \mathrm{~W} \cdot \mathrm{m}^{-1} \cdot \mathrm{K}-1$ while the simple clay has a thermal conductivity of order of $0.8 \mathrm{~W} \cdot \mathrm{m}^{-1} \cdot \mathrm{K}^{-1}$. So the clay of termite mound has better thermal resistance than simple clay. The termite clay being a very porous material, for a given volume by increasing the mass percentage of the cement, the air voids are closed, so the material is made less insulating thermally. As all materials we have studied have good thermal conductivity compared to that of cement concrete which 1.5W.m-1.K-1 [9].

\section{Resistance of test tubes to water}

Termite mounds are deemed to be resistant to rainwater. Rainwater with a significant impact on buildings built from land, water erosion often leads to collapse of buildings. In this part we have tried to determine the dissolution time of our samples in case of flood. The table below gives the dissolution time of our test specimens in water.

Published By: 


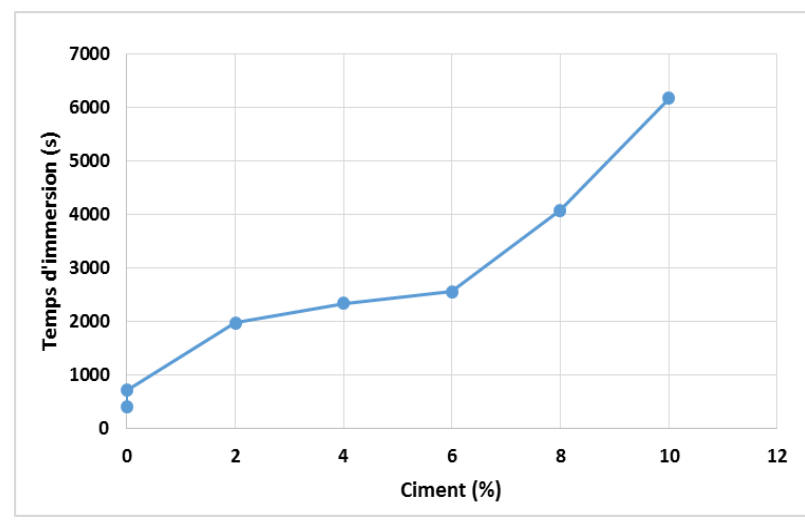

Fig. 8.Evolution of the immersion time in water according to the addition of cement

It is noted that the immersion time increases with the addition of the cement and we also note that the sample in the natural state dissolves more quickly than the stabilized cement sample, because the more the natural material is more porous hence its dissolution in water is faster.

\section{CONCLUSION}

Our main objective was to evaluate the thermal characteristics of the mound clay. In developing countries, luxury materials are those that are cement based, because in reality they offer a certain character linking durability and aesthetics. That's why we chose cement as adjuvant. Indeed, this study was conducted to achieve results that allow to fix ideas on the use of such and such materials in the building in developing countries where today it is question of low cost. We have thus tried by this study to promote locally available materials. In addition, it seems interesting to us to consider a similar study for other locally available materials. This will allow us to have enough data on the characteristics of local materials in Chad. The determination of the thermal conductivity of our samples was carried out by the box method. This method is well suited to our samples that are porous. The results obtained are very satisfactory. The addition of the cement increases the resistance to the dissolution concerning the erosion of the water of the rain, on the other hand it decreases the thermal resistance, because the cement has a conductivity higher than the clay and the mixture reduces the size of the pores. Pore is the seat of heat exchange. Thus the termite mound are thermally comfortable because of their porous structure and resistance to the erosion of rainwater.

\section{ACKNOWLEDGMENT}

We would like to thank all of our colleagues from the Energy engineering laboratory of INSTA (National Higher Institute of Sciences and Technical of Abeche, Chad) and ENSTP (National Higher School of Public Works of N'Djamena, Chad)

\section{REFERENCES}

1. G. BACHELIER, Mise au point sur l'action des termites dans les sols. S.S.C.-orstom collection de Reference 9346, 23/10/1978, pp5.

2. Vincent Freycom, « caracteristique des sol Congo » CIRAD rapport mission DynafFor avril 2014

3. Claude Girard et Michel Lepage, "Vie et mort des termitières cathedrals”, Biologie des especes, insectes n82-1991(3)-ed.opie. pp3

4. Daniel Kmiecick, les divers types d'argiles, pour la science №20, p.61, de juin 1979 ;

5. Guy Theraulaz, Andrea Perna et Pascale Kuntz, l'art de la construction chez les insectes sociaux ; Ethologie, pour la science $\mathrm{N}^{\circ} 420$ - january 2012

6. L'argile-le matériau de construction le plus ancien du monde mais aussi le plus moderne; http://www.claytec.be/fr/bauherren/know-how/

7. A. Dadi, O. Idriss M. Soultant, M.Y. Khayal Y.Elhamdouni, M. Garoum ''Effect of cow's dung on thermophysical characteristics of building materials based on clay", Research Journal of Applied Sciences, Engineering and Technology, 10(4): 464-470, 2015 ISSN: 2040-7459; e-ISSN: 2040-7467 (C) Maxwell Scientific Organization, 2015.

8. Gaye S. Caractérisation des propriétés mécaniques, acoustiques et thermiques des matériaux locaux de construction au Sénégal. Thèse de doctorat d'Etat ès Sciences Fst/Ucad, 2001.

9. BULLETIN TECHNIQUE. Cellule de mesure de conductivité EI700 ; https://www.deltalab-smt.com

10. SAINT GOBAIN, , "Introduction à la thermique du bâtiment" les essentiels de l'habitat,Edition 2016

11. Yves JANNOT, Thermique solaire, www.Thermique55.com, mars 2011.

\section{AUTHORS PROFILE}

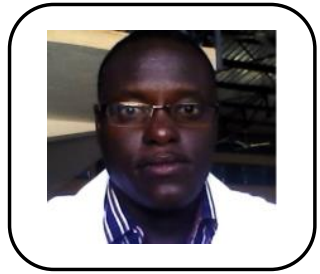

Abdallah DADI Mahamat: Teacher Research at INSTA-Abeche, Chad, doctor at the university of Thies, Senegal and postdoctoral fellow at the LERMAB laboratory of faculty of Sciences ant Technology of Nancy, University of Lorraine, France.

Email: abdallah.dadi@univ-thies.sn

1- A. Dadi, O. Idriss M. Soultant, M.Y. Khayal Y.Elhamdouni, M. Garoum "Effect of Cow's Dung on Thermophysical Charateristics of Building Materials Based on Clay". Journal : Research Journal of Applied Sciences, Engineering and Technology, 10(4): 464-470.2

2- A. Abdallah DADI Mahamat, B. Mahmoud Youssouf Khayal, C. Ahmat Charfadine, D. Malloum Soultan, E. Gilbert Menguy, F. Salif Gaye "Improvement of thermal parameters of building materials based on clay. Journal” : 2016 IEEExplore, Electronic ISBN: 978-1-5090-1864-2/16 Print on Demand(PoD): 978-1-5090-1865-9 DOI

10.1109/REDEC.2016.7577511.

3- Abdallah DADI Mahamat1, Mahamoud Youssouf Khayal2, Macodou Thiam3, Azibert Oumar Abdelakh4, Gilbert Menguy5, Salif GAYE6 “ Thermo-Physical Characterization of Clay Bricks Mixed with Agricultural Waste: Case Millet's Pod." Journal : International Journal of Emerging Technology and Advanced Engineering Site Web:http://www.ijetae.com/files/Volume6Issue1/IJETAE_0116_.pdf

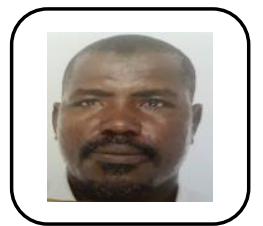

Abakar Ali, Teacher- researcher at the National School of Publics Works, obtains his Phd and Master at the faculty of Science and Technologie (FST) of Nancy, Université of Lorraine, France; Email: koudouri2019@gmail.com

1-A. Ali, Riad BENELMIR? Jean-Louis TANGUIER? Abdoulaye Saleh TODJIBAL, "Mechanical Characteristics of gum Arabie stabilized Ndjamena Clay. ISSN 1813-548X. Afrique SCIENCES 13(5) (2017) 330-341.

2-A. Ali, J.L.TANGUIER R.BENELMIR?? Abdoulaye Saleh TODJIBAL, "Mesurement of mechanical characteristics of compressed clay block stabilized by gum Arabie. ISSN 1813-548X. Afrique SCIENCES 15(1) (2019) 348-360.

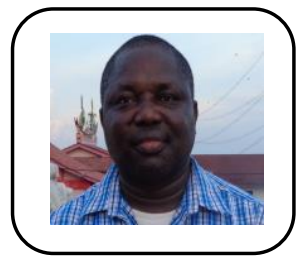

Alexis Mouangué Nanimina: Teacher Research at INSTA-Abeche, Chad, obtains his Phd and Master of sciences degrees in mechanical engineering from Univeriti Teknologi PETRONAS (UTP), Seri Iskandar, Perak, Malaysia in 2016 and 2010 respectively. Email: alexisnanichad@gmail.com

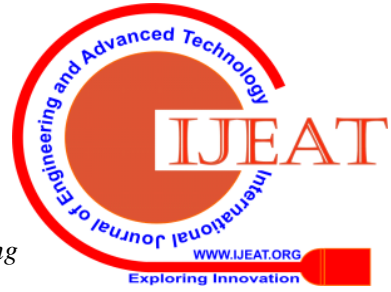


1-Alain MATIBEYE, Alexis Mouangué NANIMINA, Nandiguim LAMAÏ et Saka GONI, « Contribution à la caractérisation utilisant l'essai de traction de couches minces obtenues par pulvérisation cathodique radiofréquence », Rev. Ivoir. Sci. Technol., 32 (2018) 1 - 9.

2-. Djimako Bongo, Alexis Mouangué Nanimina, Edith Kadjangaba, Jean-Yves Champagne, « Experimental study of hydrodynamics in the aquarium using PIV method », American Journal of Energy Engineering, 2019; 7(4): 74-79.

3-Djimako Bongo, Alexis Mouangué Nanimina, Edith Kadjangaba, Jean-Yves Champagne, « Experimental study of hydrodynamics in the aquarium using PIV method », American Journal of Energy Engineering, 2019; 7(4): 74-79.

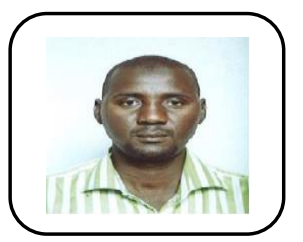

Abdallah Bannah Mahamat, Teacher Research at National higher Institute of Sciences and Technicals of Abeche, Chad INSTA. Obtains his Master of sciences degrees in mechanical engineering from National Higher Institute of Sciences and Technical of Abeche, Chad. Actually doctoral student at the Email: addibannah@yahoo.fr niversity of Ngaoundere, Cameroon 